\title{
MANGROVE FOREST EFFECT ON THE COASTLINE IN RANGSANG ISLAND RIAU PROVINCE
}

\author{
Paulinus Nadeak $^{1 *}$, Mubarak $^{2}$, Efriyeldi ${ }^{2}$ \\ ${ }^{1}$ Student of The Faculty of Fisheries and Marine Science University of Riau, Pekanbaru \\ ${ }^{2}$ Lecturer at The Faculty of Fisheries and Marine Science University of Riau, Pekanbaru \\ *paulinus2028@gmail.com
}

\begin{abstract}
The study was conducted in May-June 2019 on Rangsang Island. This study aims to determine the effect of mangrove forests on coastline found on the island of Rangsang in Riau Province. The sampling location was determined by purposive sampling, namely 3 station points, namely Segomeng Village, Tanjung Kedabu Village, and Sungai Gayung Kiri Village. Landsat image data analyzed at the Oceanographic Physics Laboratory of the Department of Marine Sciences, Faculty of Fisheries and Maritime Affairs, University of Riau. To find out the area of mangroves using Landsad 5 TM satellite imagery and Landsat 8 OLI Tirs imagery and analyzed using Er Mapper Software, Envi 4.5 and Arcgis 10.3. Calculation of the structure of the mangrove community is carried out using the line plot plot method. The results of the analysis of the vast landsat image of mangroves in the coastal areas of Rangsang Island in 1997, 2002, 2007, 2013, 2019 were respectively 11,093 ha, 10,807 ha, 10,393 ha, 10,121 ha and 9,971 ha. Changes in the coastline indicate the occurrence of abrasion and accretion, where the highest abrasion occurs at station three with an average of $-7.6 \mathrm{~m} /$ year and accretion occurs at station one with an average of $2.68 \mathrm{~m} /$ year. Mangrove density at station one is 2266.7 ind / ha and at station two that is 1466.7 ind / ha. Mangrove species found were Rhizophora apiculata, Rhizophora mucronata, Avicennia alba, Sonneratia ovata, Bruguiera gymnorrhiza, and Xylocarpus granatum.
\end{abstract}

Keywords: Image Data, Mangrove, Coastline, Island Rangsang

\section{PENDAHULUAN}

Menurut Nontji (2005) hutan mangrove merupakan tipe hutan yang khas yang terdapat di sepanjang pantai atau muara sungai yang hidupnya sangat dipengaruhi oleh pasang surut air laut. Secara ekologis hutan mangrove dapat berfungsi sebagai stabilitas atau menjaga keseimbangan ekosistem, sumber unsur hara, sebagai daerah asuhan (nursery ground), daerah mencari makan (feeding ground), dan daerah pemijahan (spawning ground). Setiawan et al. (2013), menyatakan bahwa fungsi hutan mangrove dapat digolongkan menjadi tiga macam yaitu fungsi fisik, fungsi ekologis dan fungsi ekonomis. Fungsi hutan mangrove secara fisik diantaranya: menjaga kestabilan garis pantai dan tebing sungai dari erosi atau abrasi, mempercepat perluasan lahan dengan adanya endapan lumpur yang terbawa oleh arus ke kawasan hutan mangrove, mengendalikan laju intrusi air laut sehingga air sumur disekitarnya menjadi lebih tawar, melindungi daerah di belakang hutan mangrove dari hempasan gelombang, angin kencang dan bahaya tsunami. Garis pantai merupakan batas antara darat dan laut yang seringkali mengalami perubahan bentuk 
dan posisi akibat dari kondisi lingkungan yang dinamis. Perubahan garis pantai merupakan suatu proses yang berkaitan dengan dinamika alami pantai maupun campur tangan manusia. Terjadinya perubahan garis pantai sangat dipengaruhi oleh proses yang terjadi disekitar pantai. Kerusakan yang terjadi diwilayah perisisr merupakan salah satu faktor terjadinya perubahan garis pantai.

Hakim et al. (2014) menyatakan sebagian besar pantai utara dan timur Pulau Rangsang mengalami abrasi dengan tingkat abrasi yang bervariasi. Pantai timur Pulau Rangsang merupakan pantai yang mengalami abrasi paling parah, sedangkan bagian timurnya juga terdapat sedikit sedimentasi. Pada kurun waktu 24 tahun terakhir telah terjadi abrasi di Pulau Rangsang Kabupaten Kepulauan Meranti dengan laju abrasi rata-rata 48,41 ha/tahun, dan laju sedimentasi 10,74 ha/tahun. Hal ini menunjukkan bahwa, Pulau Rangsang di Kabupaten Kepulauan Meranti mengalami pengurangan luas daratan yang cukup besar yaitu rata-rata 37.67 ha/tahun.

Pantai di Pulau Rangsang merupakan pantai yang sangat rawan mengalami abrasi, karena berhadapan langsung dengan lautan yang terbuka yaitu Selat Malaka. Kondisi tersebut menyebabkan gelombang yang terjadi akibat bangkitan angin besar yang berpotensi menyebabkan abrasi pantai. Dengan adanya keberadaan hutan mangrove yang merupakan salah satu faktor penghambat terjadinya abrasi karena keberadaan hutan mangrove dapat menghambat terjangan gelombang dan menjadi perangkap sedimen.

Keberadaan ekosistem hutan mangrove sangat penting di daerah pesisir, karena pesisir merupakan daerah yang sangat rentan dengan terjadinya abrasi maupun sedimentasi akibat aktivitasaktivitas yang terjadi baik seperti pengaruh pasang surut, pengaruh gelombang dan pengaruh lainnya yang dapat mengakibatkan perubahan garis pantai.
Melihat dari fungsi fisik mangrove sebagai pelindung pantai dari abrasi maka penulis ingin melakukan penelitian tentang seberapa besar pengaruh luas mangrove terhadap perubahan garis pantai yang terdapat di Pulau Rangsang.

Penelitian ini bertujuan untuk mengetahui perubahan garis pantai Pulau Rangsang, mengetahui luas mangrove di Pulau Rangsang, mengetahui perubahan luas garis pantai dan perubahan luas mangrove serta mengetahui bagaimana pengaruh luas hutan mangrove terhadap garis pantai yang terdapat di Pulau Rangsang Provinsi Riau.

\section{METODE PENELITIAN}

Penelitian dilaksanakan dari bulan Mei-Juni 2019. Pengambilan data lapangan dilakukan di Pulau Rangsang, Kabupaten Kepulauan Meranti, Provinsi Riau. Pengolahan data citra dan analisis data dilakukan di Laboratorium Oseanografi Fisika, Jurusan Ilmu Kelautan, Fakultas Perikanan dan Kelautan, Universitas Riau.

Pada penelitian ini digunakan metode survey yaitu dengan observasi, pengambilan data lapangan (Ground Check). Stasiun penelitian ditentukan secara purposive sampling yang artinya titik stasiun penelitian di pilih secara sengaja berdasarkan pertimbangan kondisi pesisir dengan berdasarkan hasil pengolahan data citra tahun 1997, 2002, 2007, 2013, dan 2019 yang telah diketahui pada saat interpretasi data citra. Titik stasiun penelitian ditentukan sebanyak 3 stasiun, pada setiap stasiun terdiri dari 3 transek dan pada setiap transek terdiri dari 3 plot petak contoh (Transect Line Plot). Data citra satelit Landsat 5 TM dan Landsat 8 OLI/TIRS sebagai data untuk memetakan dan menganalisis perubahan luas dan kerapatan vegetasi mangrove.

\section{Pengolahan Data Citra}

Pengolahan citra dilakukan untuk mengetahui luas mangrove, dan perubahan 
garis pantai. Pengolahan citra pertama kali didownload dari USGS yaitu citra tahun 1997, 2002, 2007, 2013, dan 2019. Kemudian data tersebut akan diolah terlebih dahulu menggunakan sofware penginderaan jauh untuk mendapatkan data luas hutan mangrove dan garis pantai.

Koreksi radiometrik bertujuan untuk memperbaiki nilai piksel supaya sesuai dengan yang seharusnya, dengan mempertimbangkan faktor gangguan atmosfer sebagai sumber kesalahan utama. Efek atmosfer menyebabkan nilai pantulan objek di permukaan bumi yang terekam oleh sensor menjadi bukan merupakan nilai aslinya, tetapi menjadi lebih besar oleh karena adanya hamburan atau lebih kecil karena proses serapan. Untuk melakukan koreksi pada tahap ini digunakan metode penyesuaian histogram (histogram adjustment) yang berdasarkan pada pemrosesan nilai digital oleh sensor. Objek yang memberikan respon spectral yang paling rendah seharusnya bernilai 0 , apabila nilai ini ternyata melebihi angka 0 maka nilai tersebut dihitung sebagai bias dan koreksi dilakukan dengan mengurangi seluruh nilai pada saluran tersebut dengan biasnya.

Pembuatan Citra komposit digunakan untuk mengenali objek pada citra. Untuk memudahkan pengenalan objek pada citra maka digunakan komposit semu. Pada penelitian ini komposit yang digunakan komposit RGB453 pada Landsat-5 sedangkan komposit RGB564 pada Landsat-8 (Hendrawan et al., 2018).

Pemotongan citra dilakukan untuk memfokuskan kajian pada daerah penelitian dan objek pada masing masing citra komposit warna semu masing-masing band. Selain itu, pemotongan citra akan mengurangi kapasitas memori sehingga memudahkan pada proses pengolahan data citra tersebut (Pinastika et al., 2013).

Klasifikasi dilakukan untuk mendapatkan peta tematik, yakni suatu peta yang terdiri dari bagian-bagian yang telah dikelompokan kedalam kelas-kelas tertentu yang merepresantasikan suatu kelompok objek yang sama. Pada penelitian ini digunakan klasifikasi terbimbing (Supervised), dimana citra diklasifikasikan dengan metode kemiripan maksimum (maximum likehood). Dimana kelas-kelas yang digunakan yaitu kelas laut dalam, kelas laut dangkal, kelas vegetasi mangrove, dan kelas non vegetasi mangrove. Dari pembagian kelas kelas tersebut kita dapat menentukan vegetasi mangrove.

\section{HASIL DAN PEMBAHASAN Perubahan Luas Vegetasi Mangrove Tahun 1997, 2002, 2007, 2013 dan 2019}

Berdasarkan hasil pengolahan data citra menggunakan teknik interpretasi citra digital diperoleh layout berupa peta sebaran mangrove. Untuk Peta tutupan lahan mangrove di Pulau Rangsang disajikan pada gambar 1,2,3,4, dan 5 . 


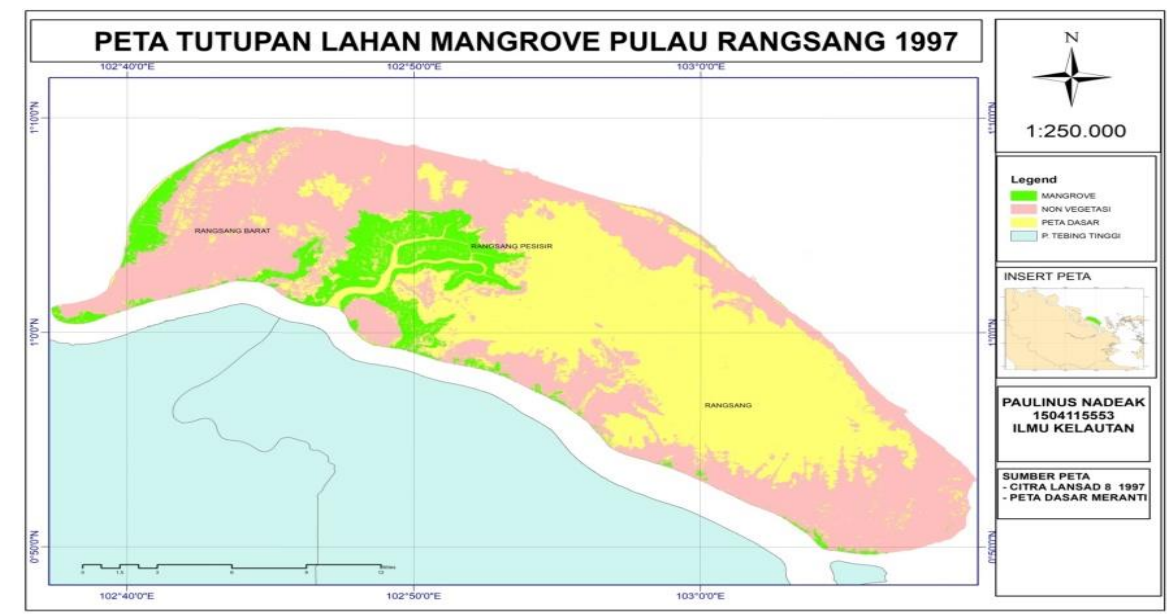

Gambar 1. Peta Tutupan Lahan Mangrove Pulau Rangsang Tahun 1997

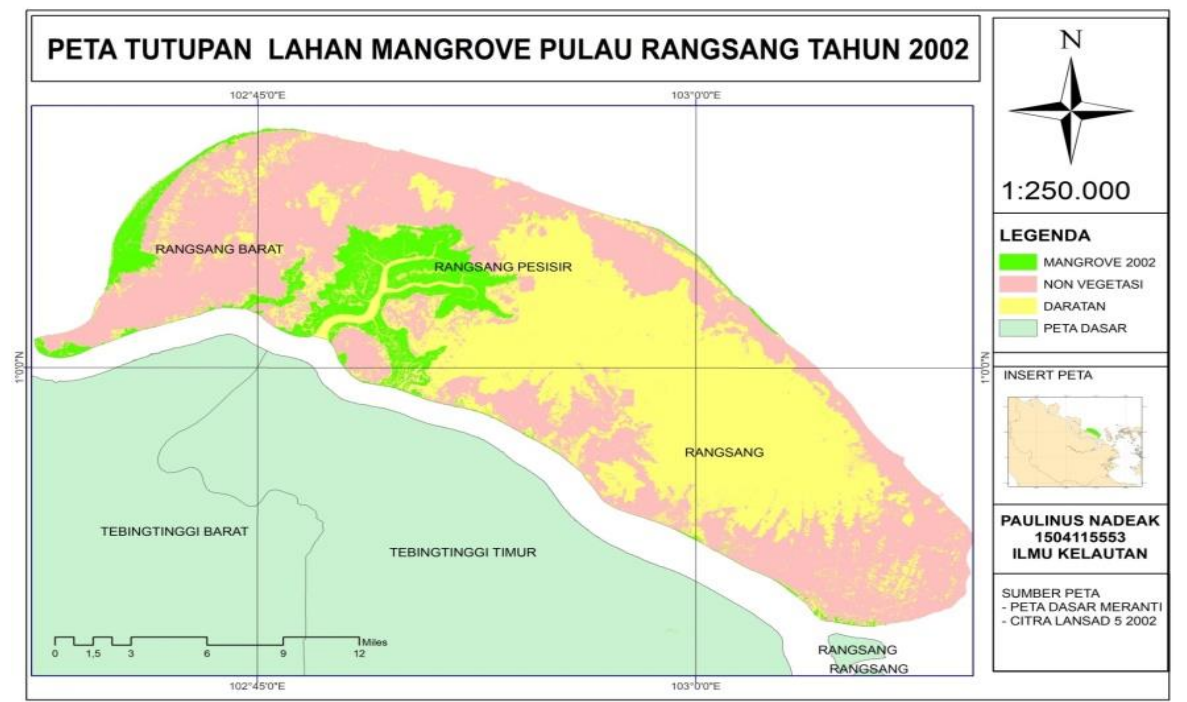

Gambar 2. Peta Tutupan Lahan Mangrove Pulau Rangsang Tahun 2002

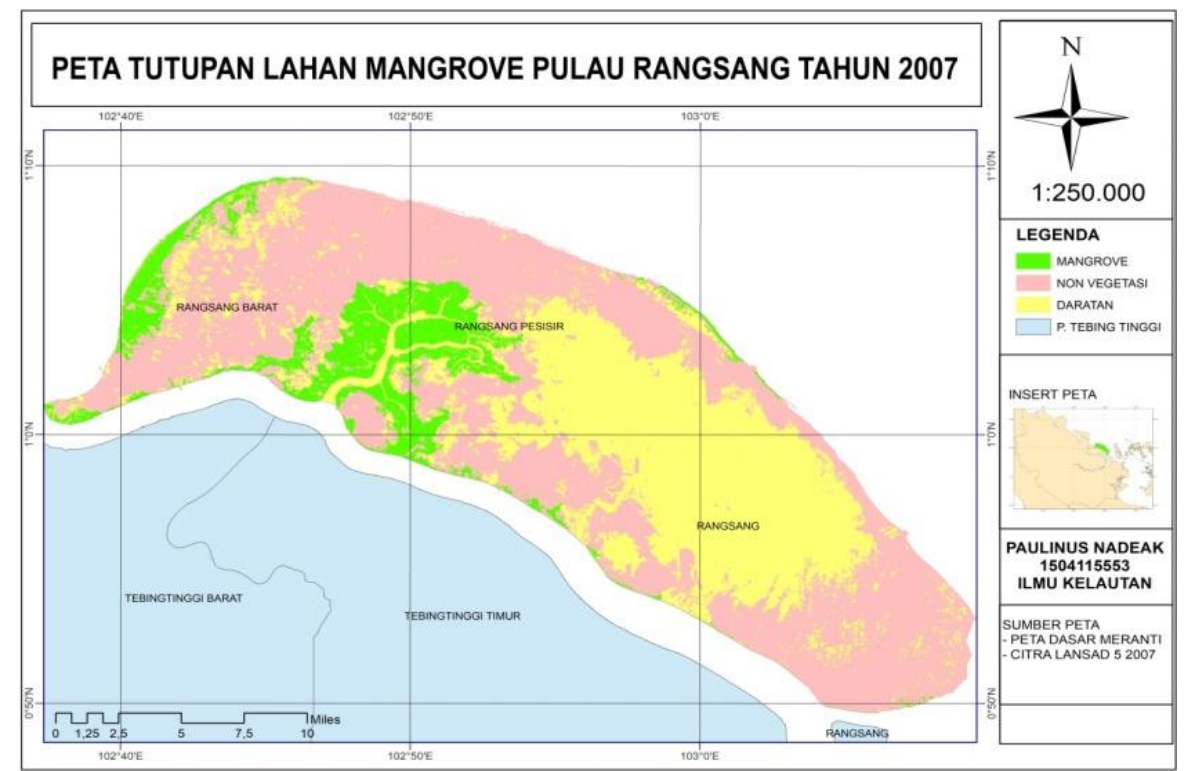

Gambar 3. Peta Tutupan Lahan Mangrove Pulau Rangsang Tahun 2007 


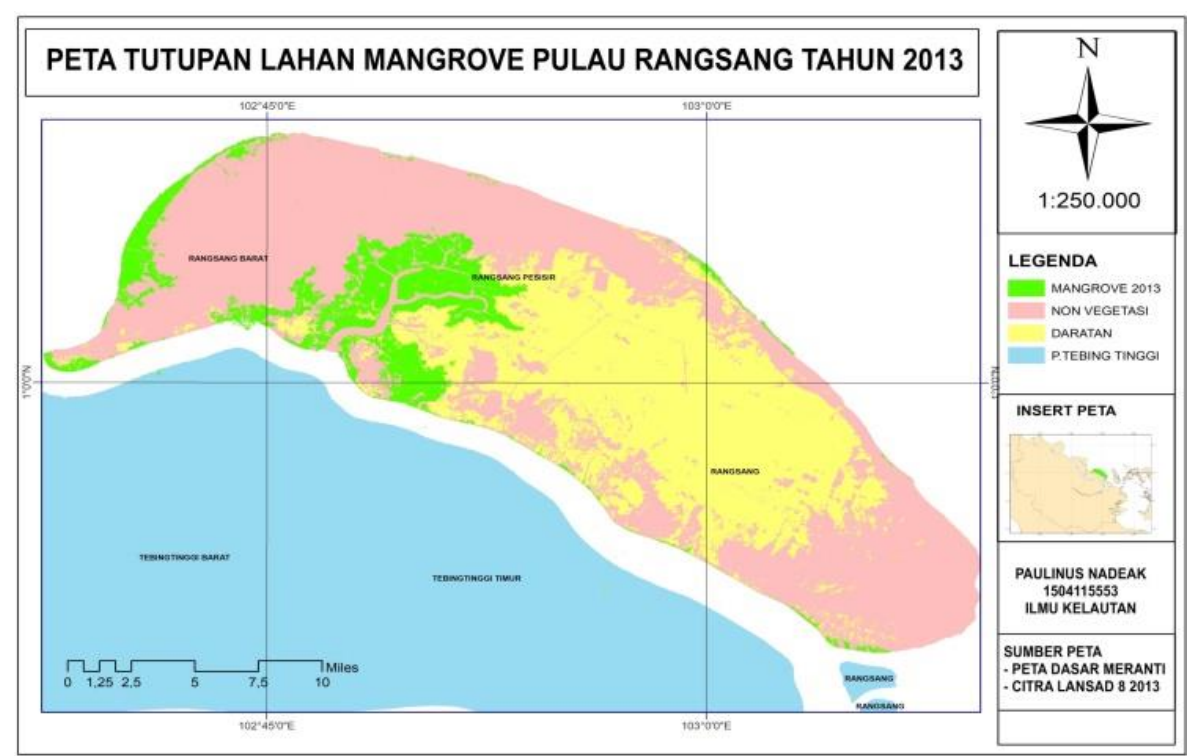

Gambar 4. Peta Tutupan Lahan Mangrove Pulau Rangsang Tahun 2013

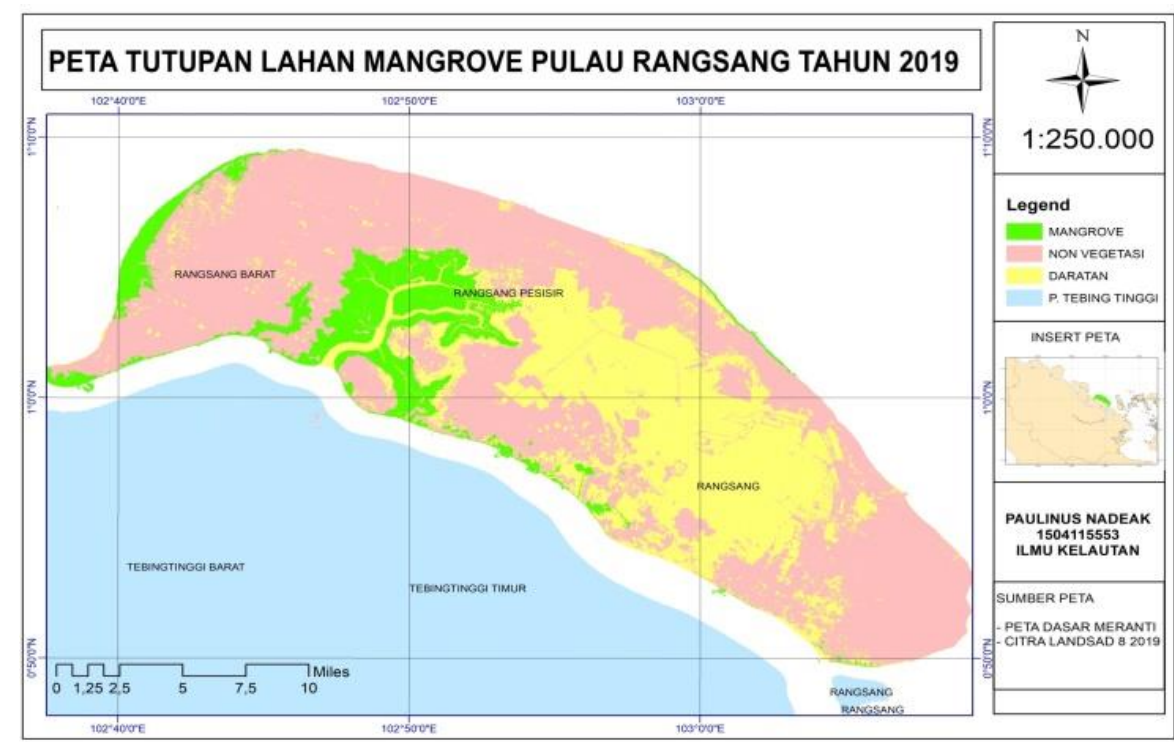

Gambar 5. Peta Tutupan Lahan Mangrove Pulau Rangsang Tahun 2019

Perubahan luas vegetasi mangrove di Pulau Rangsang tahun 1997-2019 disajikan dalam Tabel 1.

Tabel 1. Perubahan Luas Vegetasi Mangrove Di Pulau Rangsang 1997-2019

\begin{tabular}{ccc}
\hline No & Tahun & Luas (ha) \\
\hline 1 & 1997 & 9.759 \\
2 & 2002 & 9.397 \\
3 & 2007 & 8.911 \\
4 & 2013 & 8.297 \\
5 & 2019 & 7.875 \\
\hline
\end{tabular}

Perubahan luasan mangrove dapat diketahui melalui proses klasifikasi secara spasial dengan menggunakan aplikasi sistem informasi geografis (Arcgis versi 10.3). Data tutupan lahan merupakan data shapfile yang diubah menjadi polygon agar didapat berapa luas area mangrove yang mengalami perubahan. Dari hasil hitungan tersebut didapat jumlah luas area mangrove pada tahun 1997 seluas 9.759 ha, tahun 2002 seluas 9.397 ha, tahun 2007 seluas 8.911 ha, tahun 2013 seluas 8.297 ha dan tahun 2019 seluas 7.875 ha. Dari hitungan tersebut berarti luas area mangrove pada 
pesisir Pulau Rangsang mengalami pengurangan luas disetiap tahunnya. Dari hasil luasan tersebut, dapat dilakukan proses gabungan untuk mendapat area perubahan mangrove

Dari hasil pengolahan data citra secara multispektral diketahui bahwa luasan mangrove di Pulau Rangsang mengalami penurunan setiap 5 tahunnya selama 22 tahun terahir Hal ini disebabkan oleh perusakan atau penebangan liar terhadap mangrove untuk dijadikan bahan dasar arang oleh perusahaan" arang maupun disebabkan faktor alam dari alam seperti hantaman gelombang dan yang lainya. Muryani et al. (2011) menyatakan bahwa kegiatan pembangunan utama yang memberikan sumbangan terbesar terhadap penurunan mangrove di Indonesia adalah pengambilan kayu untuk keperluan komersil serta peralihan peruntukan untuk tambak dan areal pertanian.

Khomsin dalam Fadlan (2011) menyatakan bahwa kerusakan alamiah yang terjadi pada ekosistem hutan mangrove timbul karena peristiwa alam seperti adanya gelombang besar dan dapat menyebabkan tercabutnya tanaman muda atau tumbangnya pohon. Pada umumnya kerusakan ekosistem hutan mangrove disebabkan oleh aktivitas manusia dalam pendayagunaan sumberdaya alam wilayah pantai tidak memperhatikan kelestarian, sepeti penebangan untuk keperluan kayu bakar yang berlebihan, pembukaan lahan untuk tambak dan pertambangan. Dari hasil analisis citra penurunan luas hutan mangrove terbesar terjadi antara tahun 2007 sampai tahun 2013 dimana berkurangnya luasan hutan mangrove mencapai 614 Ha. Sebagian besar penurunan ini disebabkan oleh pembabatan besar-besaran yang dilakukan masyarakat dan perusahaan arang yang terdapat di Pulau Rangsang. Berdasarkan data Dinas Perindustrian dan Perdagangan, jumlah lokasi dan kapasitas produksi perusahaan industri arang bakau terdapat 14 perusahaan berlokasi di Kecamatan Rangsang dengan kapasitas produksi $1.540 /$ ton.

Penurunan luas hutan mangrove terkecil terjadi antara tahun 2013 sampai tahun 2019 dimana penurunan luas hutan mangrove sekitar 230 ha. Hal ini disebabkan adanya upaya dari masyarakat dan pemerintah untuk menjaga dan mempertahankan hutan mangrove yang ada di Pulau Rangsang. Halida (2019) menyatakan luas hutan mangrove di Desa Anak Setatah mengalami peningkatan sekitar 146,87 ha. Kegiatan konservasi mangrove oleh instansi pemerintah maupun masyarakat yang tinggal di Desa Anak Setatah. Selain instansi pemerintah, masyarakat membentuk kelompok pelestari wilayah pesisir yang diberi nama TEGAS.

\section{Perubahan Garis Pantai Pulau Rangsang} Perbedaan Perubahan garis pantai Pulau Rangsang pada stasiun 1, 2 dan 3 dapat dilihat pada Gambar 3 dan 4.

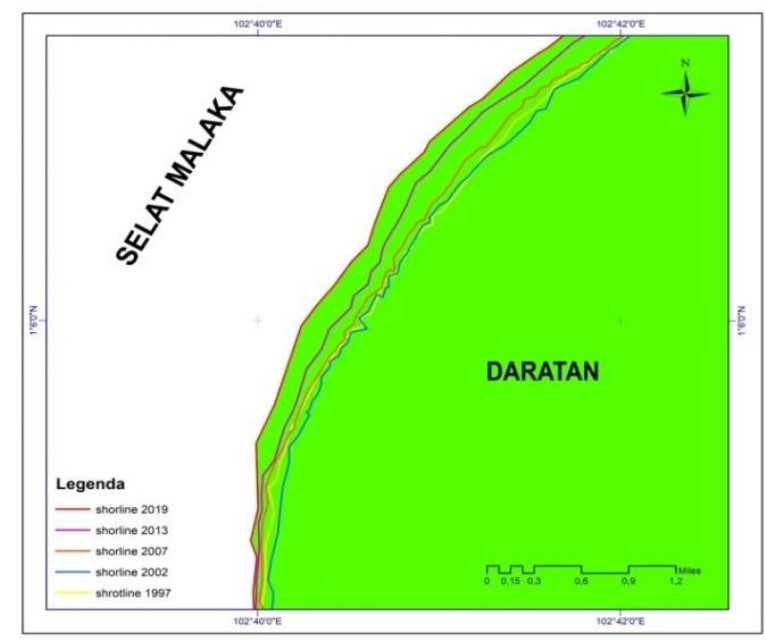

Gambar 6. Perubahan Garis Pantai Stasiun 1 


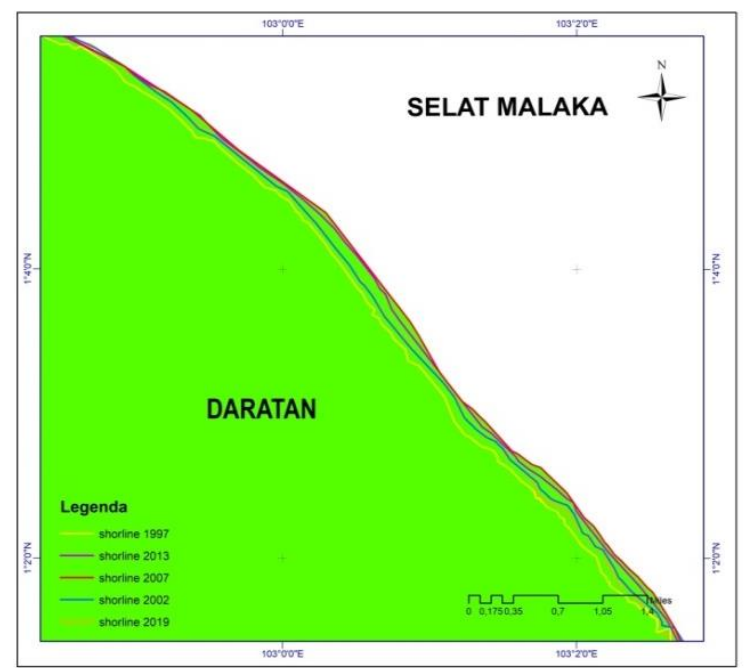

Gambar 7. Perubahan Garis Pantai Stasiun 2

Dari gambar diatas ditemukan adanya perubanahan garis pantai. Perubahan Garis

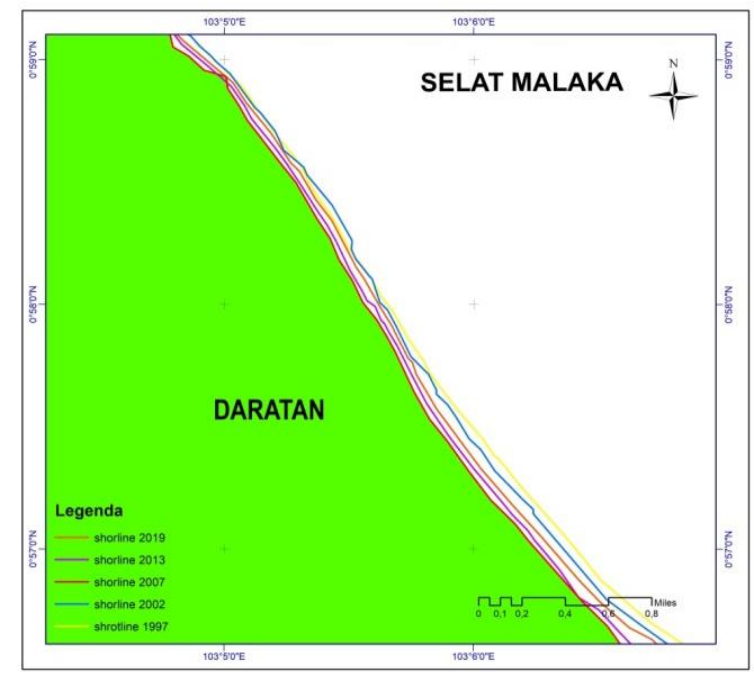

Gambar 8. Perubahan Garis Pantai Stasiun 3

pantai di Pulau Rangsang disajikan pada Tabel 2.

Tabel 2. Perubahan Garis Pantai Pulau Rangsang (1997-2019).

\begin{tabular}{|c|c|c|c|c|c|c|}
\hline Stasiun & $\begin{array}{c}\text { Tahun } \\
\text { 1997-2002 } \\
(\mathrm{m}) \\
\end{array}$ & $\begin{array}{c}\text { Tahun } \\
2002-2007 \\
(\mathrm{~m}) \\
\end{array}$ & $\begin{array}{c}\text { Tahun } \\
2007-2013 \\
(\mathrm{~m}) \\
\end{array}$ & $\begin{array}{c}\text { Tahun } \\
2013-2019 \\
(\mathrm{~m}) \\
\end{array}$ & $\begin{array}{c}\text { Rata-Rata Laju } \\
\text { Perubahan } \\
\text { (m/thn) }\end{array}$ & Keterangan \\
\hline 1 & $+10,13$ & $+17,49$ & $+5,84$ & $+25,56$ & $+2,68 \mathrm{~m} / \mathrm{thn}$ & \\
\hline 2 & $+12,86$ & $+11,38$ & $+2,5$ & +14.76 & $+1,88$ & Akresi \\
\hline 3 & $-36,38$ & $-38,57$ & $-59,57$ & $-34,17$ & $-7,66 \mathrm{~m} / \mathrm{thn}$ & Abrasi \\
\hline
\end{tabular}

Kerapatan Vegetasi Mangrove Tiap Stasiun Pada Tahun 2019 Berdasarkan Struktur Komunitas
Kerapatan vegetasi mangrove berdasarkan struktur komunitas tingkat pohon tiap stasiun sampling disajikan pada Tabel 3.

Tabel 3. Kerapatan vegetasi mangrove tiap stasiun pada tahun 2019

\begin{tabular}{cllcllc}
\hline $\begin{array}{c}\text { Titik } \\
\text { Stasiun }\end{array}$ & Nama Desa & Kerapatan & $\begin{array}{c}\text { Jumlah Pohon } \\
\text { (ind/ha) }\end{array}$ & Kerapatan & $\begin{array}{l}\text { Jumlah anakan } \\
\text { (ind/ha) }\end{array}$ & $\begin{array}{c}\text { Titik } \\
\text { Stasiun }\end{array}$ \\
\hline 1. & Segomeng & Padat & 2266,7 & Padat & 2266,7 & 1. \\
2. & Tanjung & Sedang & 1466,7 & Padat & 1600 & 2. \\
\hline
\end{tabular}

Keterangan : $(-)=$ Tidak Ditemukan

Kerapatan vegetasi mangrove
berdasarkan $\begin{gathered}\text { momunitas } \\ \text { struktur }\end{gathered}$
menunjukkan bahwa kerapatan tertinggi
terdapat pada stasiun 1, yaitu Desa
Segomeng dengan 2266,7 ind/ha dan
untuk kerapatan anakan tertinggi terdapat
pada Segomeng 22266,7 ind/ha.
Berdasarkan KepMen LH No 201 Tahun
2004 menyatakan bahwa kriteria baku kerusakan mangrove dikatakan sangat baik apabila kerapatannya $\geq 1.500 \mathrm{ind} / \mathrm{ha}$, sedangkan kriteria sedang apabila kerapatan mangrovenya $\geq 1.000 \leq 1.500$ ind/ha dan kriteria jarang apabila kerapatan mangrovenya $<1000$ ind/ha. Dari hasil perhitungan struktur komunitas mangrove bahwa di stasiun satu dapat disimpulkan bahwa mangrove dalam 
keadaan baik dan pada stasiun dua mangrove dalam keadaan sedang.

\section{Faktor Sosial Ekonomi Terhadap Mangrove}

Keterdapatan hutan mangrove bagi masyarakat di Pesisir Pulau Rangsang memberikan manfaat langsung terhadap sosial perekonomian masyarakat. Namun disisi lain kawasan hutan mangrove ini mendapat banyak tekanan, berupa aktivitas perambahan kawasan hutan mangrove yang dilakukan oleh masyarakat di sekitar kawasan hutan mangrove. Perambahan hutan mangrove dilakukan untuk membuka areal lahan dan penggunaan kayu vegetasi mangrove sebagai bahan bangunan, kayu bakar, dan arang yang dilakukan oleh penduduk asli karena mahalnya bahan bakar, serta pabrik arang di Pulau Rangsang.

Kurangnya pengetahuan masyarakat mengenai manfaat dan fungsi hutan mangrove serta tingkat pendidikan formal yang masih tergolong rendah menyebabkan masyarakat kurang memperhatikan keberadaan hutan mangrove dan melakukan kegiatan konversi tanpa memperhatikan ketersediaan hutan mangrove untuk masa yang akan datang. Permasalahan utama tentang pengaruh atau tekanan terhadap habitat mangrove bersumber dari keinginan masyarakat pembabatan mangrove untuk dijual kayunya. Selain itu juga meningkatnya permintaan terhadap produksi kayu yang menyebabkan eksploitasi berlebihan terhadap vegetasi hutan mangrove. Dalam situasi seperti ini, habitat dasar dan fungsi dari hutan mangrove menjadi hilang.

Dahuri et al. (1996) menyatakan bahwa salah satu penyebab kerusakan wilayah pesisir adalah aktivitas perekonomian yang tidak terkendali dan kesadaran pentingnya upaya pelestarian sumberdaya alam wilayah pesisir yang masih rendah dikalangan lintas pelaku.
Berdasarkan pengamatan dan hasil wawancara yang dilakukan terhadap masyarakat pesisir Pulau Rangsang diketahui bahwa mayoritas masyarakat yang tinggal di Pesisir menggantungkan perekonomiannya pada sumberdaya laut dan pesisir baik sebagai nelayan, pengelolah tempat wisata pantai, maupun sebagai pemberi jasa angkutan umum yang merupakan alat trasportasi. Lokasi permukiman yang terlalu dekat dengan ekosistem mangrove bahkan langsung memanfaatkan lahan mangrove menjadi salah satu pemicu rusaknya ekosistem hutan mangrove. Beberapa kegiatan masyarakat yang merusak ekosistem mangrove seperti melakukan penebangan mangrove untuk dijual sebagai bahan dasar kayu arang. Akibat akitivitas sosial dan ekonomi masyarakat di Pulau Rangsang yang akan menimbulkan dampak negatif terhadap lingkungan secara langsung maupun tidak langsung.

\section{KESIMPULAN DAN SARAN Kesimpulan}

Luas mangrove di wilayah pesisir Pulau Rangsang pada tahun 1997, 2002, 2007, 2013, 2019 secara berurutan sebesar 11.093 ha, 10.807 ha, 10.393 ha, 10.121 dan 9.971 ha. Luasan vegetasi mangrove di Pesisir Pulau Rangsang mengalami penurunan setiap tahunnya dan penurunan tertinggi pada tahun 2002-2007 yaitu sebesar 414 ha. Hasil analisis survey lapangan menunjukkan bahwa mangrove di Pulau Rangsang memiliki kerapatan padat pada stasiun 1 dan kerapatan sedang pada stasiun 2.

Perhitungan perubahan garis pantai dengan menggunakan perangkat lunak dengan metode tumpang susun pada Pulau Rangsang pada tahun 1997-2019 mengalami akresi dan abrasi. Abrasi tertinggi terjadi pada stasiun tiga yaitu dengan rata- rata $-7,66 \mathrm{~m} /$ tahun dan akresi terjadi pada stasiun 1 dengan rata-rata akresi 2,68 m/tahun. Abrasi tertinggi 
terjadi tahun 2007-2013 pada pesisir Pulau

Rangsang terabrasi mencapai 1143 ha.

\section{DAFTAR PUSTAKA}

1. Dahuri, R. (2003). Keanekaragaman Hayati Laut. Aset Pembangunan Berkelanjutan Indonesia. Gramedia Pustaka Utama. Jakarta.

2. Dahuri, R., J. Rais., S.G. Putra, dan M.J. Sitepu. (2001). Pengelolaan Sumber daya Wilayah Pesisir dan Lautan Secara Terpadu. PT. Pradnya Paramita, Jakarta.

3. Hakim A.R., S. Sutikno, dan M. Fauzi. (2014). Analisis Laju Abrasi Pantai Pulau Rangsang di Kabupaten Kepulauan Meranti dengan Menggunakan Data Satelit. Jurnal Sains dan Teknologi. Volume 13(2), Pages 57-62.

4. Fadlan, M. (2010). Aktivitas Ekonomi Penduduk Terhadap Kerusakan Ekosistem Mangrove di Kelurahan Bagan Deli Kecamatan Medan Belawan. Universitas sumatera utara. Medan

5. Halida. (2018). Pemetaan Perubahan Luas Mangrove Menggunakan Citra Landsat di Kecamatan Rangang Barat. Skripsi. Fakultas Perikanan dan Kelautan Universitas Riau. Pekanbaru.

6. Hendrawan. J.I. Gaol dan S.B. Susilo. (2018). Studi Kerapatan dan Perubahan Tutupan Mangrove Menggunakan Citra Satelit di Pulau Sebatik Kalimantan Utara. Jurnal Ilmu dan Teknologi Kelautan Tropis, Volume 10(1), Pages 99-109

7. Nontji, A. (2005). Laut Nusantara. Cetakan Keempat. Djambatan. Jakarta.

8. Pinastika. N., S. Subiyanto, dan B. Sasmito. (2013). Pemetaan Total Suspended Solid (TSS) Menggunakan Citra Satelit Multi Temporal di Danau Rawa Pening Provinsi Jawa Tengah. Jurnal Geodesi Undip, Volume 2(4), Pages 72-84.

9. Setyawan, A.D., A. Susilowati, dan Sutarno. (2002). Biodiversitas Genetik, Spesies dan Ekosistem Mangrove di Jawa Petunjuk Praktikum Biodiversitas: Studi Kasus Mangrove. Jurusan Biologi. Fakultas Matematika dan Ilmu Pengetahuan Alam. Universitas Sebelas Maret. Surakarta. 